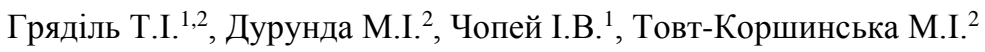

\title{
Порівняльний аналіз впливу різних груп цукрознижуючих препаратів на показники вуглеводного та ліпідного обміну у паціснтів 3 цукровим діабетом 2-го типу
}

\author{
ДВНЗ «Ужгородський національний університет», м. Ужгород, Україна: \\ ${ }^{1}$ Факультет післядипломної освіти та доуніверситетської підготовки, кафедра терапії та сімейної медицини \\ ${ }^{2}$ Медичний факультет № 2, кафедра внутрішніх хвороб \\ mar-durunda@ukr.net, ivchopey@hotmail.com
}

\footnotetext{
Грядиль Т.И. ${ }^{1,2}$, Дурунда М.И. ${ }^{2}$,

Чопей И.В. ${ }^{1}$, Товт-Коршинска М.И. ${ }^{2}$

Сравнительный анализ влияния разных групп

сахароснижающих препаратов на показатели

углеводного и липидного обмена у пациентов с сахарным диабетом 2-го типа

ГВУЗ «Ужгородский национальный университет», г. Ужгород, Украина:

${ }^{1}$ Факультет последипломного образования и довузовской подготовки, кафедра терапии и семейной медицины

${ }^{2}$ Медицинский факультет № 2,

кафедра внутренних болезней
}

\author{
Griadil T.I. ${ }^{1,2}$, Durunda M.I. ${ }^{2}$, \\ Chopey I.V. ${ }^{1}$, Tovt-Korshynska M.I. ${ }^{2}$ \\ Comparative analysis of influence of different groups \\ on drugs hypoglycemic carbohydrate and lipid \\ metabolism in patients with type 2 diabetes mellitus \\ SHEI "Uzhhorod National University", Uzhhorod, Ukraine: \\ ${ }^{1}$ Faculty of Postgraduate Education and Pre-University \\ Training, Department of Therapy and Family Medicine \\ ${ }^{2}$ Faculty of Medicine № 2, Department of Internal Diseases
}

\section{Вступ}

В Україні кількість хворих на ЦД 2-го типу станом на 2017 рік складає близько 1 млн 200 тис. осіб, натомість у світі ця цифра зростає до понад 422 млн осіб [2].

Згідно останніх рекомендацій American Diabetes Association (ADA) та the European Association for the Study of Diabetes (EASD) в лікуванні хворих на ЦД 2-го типу використовують наступні групи цукрознижувальних препаратів: 1) похідні бігуаніду (метформін) 2) глітазони (піоглітазон, розіглітазон, та ін.), 3) похідні сульфонілсечовини (гліклазид, глімепірид, гліпізид, гліквідон, та ін.), 4) антагоністи рецептора глюкагоноподібного пептиду-1 (ГПП-1) (ексенатид, ліраглутид, ліксисенатид, та ін.), 5) інгібітори натрій-глюкозного котранспортера 2 (SGLT-2) (дапагліфлозин, канагліфлозин, емпагліфлозин, та ін.), 6) інгібітори дипептидилпептидази - 4 (ДПП-4) (ситагліптин, лінагліптин, вілдагліптин, та ін.), 7) препарати інсуліну [4,5].

Натомість в Україні з метою лікування пацієнтів 3 ЦД 2-го типу поки все ще дійсний та використовується Наказ МО3 України від 21 грудня 2012 року № 1118, Уніфікований клінічний протокол первинної та вторинної (спеціалізованої) медичної допомоги ЦД 2-го типу, який потребує перегляду з врахуванням сучасних даних [2].

Зазвичай стартова терапія всім хворим з ЦД 2-го типу починається з метформіну, а якщо через 3 місяці не було досягнуто зниження глікованого гемоглобіну (HbA1C) до цільового рівня, менше 6,5\%, призначався додатково препарат другої лінії у відповідності до фаз розвитку ЦД $[4,5]$.

Незважаючи на широкий асортимент використання антидіабетичних препаратів, досягнення компенсації метаболічних порушень, попередження інвалідизації, покращення якості життя та запобігання втрати працездатності у багатьох осіб 3 ЦД 2-го типу залишаються все ще не вирішеними цілями [3].

Через те, що понад $60 \%$ пацієнтів мають декомпенсований перебіг ЦД 2-го типу, це тільки сприяє прогресуванню [6,7]. Одним із найчастіших ускладнень ЦД 2-го типу $є$ діабетична нефропатія, якій передують мікроальбумінурія, макроальбумінурія та протеїнурія [7]. Діабетична кардіоміопатія виникає в результаті порушення регуляції метаболізму глюкози і ліпідів, пов'язаного з ЦД, що призводить до посилення окисного стресу та активації множинних запальних шляхів, які опосередковують клітинне і позаклітинне пошкодження, патологічне ремоделювання серця та діастолічну й систолічну дисфункцію $[8,9]$.

Мета: вивчити вплив різних схем лікування у хворих на ЦД 2 типу при супутньому ожирінні на показники вуглеводного та ліпідного обміну. 


\section{Матеріали та методи}

На базі терапевтичного відділення комунального некомерційного підприємства «Ужгородська районна клінічна лікарня Ужгородської районної ради Закарпатської області» було обстежено 87 пацієнтів 3 діагнозом ЦД 2-го типу в період з квітня 2019 по лютий 2020 року. Всім обстеженим пацієнтам проводили на етапі госпіталізації загальноклінічні обстеження, в тому числі визначали показники вуглеводного та ліпідного обміну. Додатково збирали лабораторні дані анамнестично за 6 місяців давності та більше до госпіталізації за допомогою даних медичної документації, а також в часовому проміжку через 6 місяців, після стаціонарного лікування на амбулаторному прийомі.

Діагноз цукрового діабету 2 типу підтверджували згідно із рекомендаціями Наказу МО3 України від 21.12.2012 № 1118 «Уніфікованого клінічного протоколу первинної та вторинної (спеціалізованої) медичної допомоги «Цукровий діабет 2 типу»»».

Діагноз ЦД підтверджували, згідно 3 критеріями експертного комітету 3 діагностики та класифікації ЦД (2012), якщо в медичній документації було зафіксовано один 3 наступних критеріїв: НbA1c $>6,5 \%$, глюкоза плазми натще $\geq 7,0$ ммоль/л, постпрандіальна глікемія через 2 години $\geq 11,0$ ммоль/л.

В залежності від лікування всіх обстежених пацієнтів було поділено на наступні групи: I - група (n=22) отримувала метформіну у дозі 850 мг 2 рази, II група $(\mathrm{n}=18)$ отримувала комбінацію метформіну у дозі 850 мг 2 рази та глімепірид 2 мг/добу, III - група (n=21) отримувала ін'єкційний інсулін (II) по схемі, IV - група (n=13) - отримувала комбінацію II по схемі та метформіну у дозі 850 мг 2 рази, V - група $(\mathrm{n}=13)$ - отримувала комбінацію 5 мг емпагліфлозину та 850 мг метформіну $1 \mathrm{p} /$ д.

Bce назначене лікування даним пацієнтам відповідало наказу МО3 України, від 21.12.2012 № 1118
«Уніфікований клінічний протокол первинної та вторинної (спеціалізованої) медичної допомоги ЦД 2 типу 2012 року» щодо надання допомоги пацієнтам з ЦД 2 типу та останніми рекомендаціями Американської та Європейської асоціацій діабетологів [2,4].

Статистичну обробку результатів дослідження було виконано за допомогою електронних таблиць Excel for Windows, яка входить у пакет програм Microsoft Office 2010, та програми STATISTICA 8.0.

Статистичний аналіз матеріалів, зведення результатів та узагальнення висновків виконані методом варіаційної статистики 3 урахуванням середніх величин (мода, медіана, середнє арифметичне) і середньої похибки $(\mathrm{M} \pm \mathrm{m})$ з оцінюванням достовірності значень за t-критерієм Стьюдента, а також із визначенням коефіцієнта кореляції за допомогою парного методу Пірсона для виявлення зв'язків між отриманими показниками. За мінімальний поріг вірогідності приймали значення $\mathbf{p}<0,05$. Перевірку нормальності розподілу параметричних характеристик здійснювали за критерієм Шапіро-Вілкса.

\section{Результати дослідження та їх обговорення}

Із 87 пацієнтів включених в дослідження 71\% були жінки та 29\% чоловіки. Вік обстежених пацієнтів був у

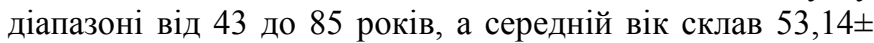
1,02 років. Тривалість захворювання на ЦД 2 типу коливалася від 2 до 15 років.

Дані результатів приведені у табл. 1, 2.

Звертає на себе увагу, що у всіх групах хворих відмічається зниження рівня глюкози та глюкозильованого гемоглобіну після лікування, але дані носять статистично не достовірний характер $(\mathrm{p}>0,05)$, окрім I, II та V груп, де результат має статистично достовірний характер ( $<<0,05)$. Слід відмітити, що тільки в групах I та V було досягнуті цільові рівні НbA1c через 6 місяців лікування та спостереження 3 моменту виписки (табл. 1).

Таблиця 1. Динаміка рівня показників глюкози та НbА1с у паціснтів з цукровим діабетом до, на момент госпіталізації та через 6 місяців після лікування $(\mathrm{M} \pm \mathbf{m})$

\begin{tabular}{|c|c|c|c|c|c|}
\hline \multirow{2}{*}{ Показник } & \multicolumn{5}{|c|}{ Група паціснтів в залежності від лікування } \\
\hline & I (n=22) & II $(\mathbf{n = 1 8})$ & III (n=21) & IV (n=13) & $V(n=13)$ \\
\hline Глюкоза до госпіталізації (ммоль/л) & $10,50 \pm 0,74$ & $11,94 \pm 1,08$ & $12,8 \pm 1,35$ & $14,47 \pm 1,76$ & $13,7 \pm 0,9$ \\
\hline $\begin{array}{l}\text { Глюкоза під час госпіталізації після } \\
\text { призначеного лікування (ммоль/л) }\end{array}$ & $6,76 \pm 0,41 * 1$ & $6,63 \pm 1,14 \#^{1}$ & $7,37 \pm 0,7 €^{1}$ & $8,4 \pm 2,0 \S^{1}$ & $7,8 \pm 0,7 ¥ 1$ \\
\hline $\begin{array}{l}\text { Глюкоза через } 6 \text { місяців після виписки } \\
3 \text { лікарні (ммоль/л) }\end{array}$ & $6,5 \pm 0,34 * 2$ & $6,2 \pm 0,7 \#^{2}$ & $7,02 \pm 0,55 €^{2}$ & $7,6 \pm 1,3 \S^{2}$ & $7,0 \pm 0,4 ¥^{2}$ \\
\hline HbA1c, до госпіталізації (\%) & $8,05 \pm 0,9$ & $8,5 \pm 2,25$ & $8,4 \pm 0,7$ & $10,5 \pm 0,5$ & $10 \pm 0,55$ \\
\hline $\begin{array}{l}\text { HbA1c, під час госпіталізації після } \\
\text { призначеного лікування (\%) }\end{array}$ & $7,8 \pm 0,7 * 1$ & $8,3 \pm 1,25 \#^{1}$ & $8,4 \pm 0,5 €^{1}$ & $9,3 \pm 0,3 \S^{1}$ & $9,5 \pm 0,7 ¥^{1}$ \\
\hline $\begin{array}{l}\text { НbA1c через } 6 \text { місяців після виписки } \\
3 \text { лікарні (\%) }\end{array}$ & $6,4 \pm 0,5 * 2$ & $6,8 \pm 0,75 \#^{2}$ & $7,8 \pm 0,75 €^{2}$ & $7,3 \pm 0,4 \S^{2}$ & $6,2 \pm 0,4 ¥^{2}$ \\
\hline $\begin{array}{l}\text { Примітки: } \\
\text { HbА1c - глікований гемоглобін; } \\
1 \text { - при порівянні між показниками до г } \\
2 \text { - при порівянні між показниками під }\end{array}$ & іттапіза & ерез 6 мі & 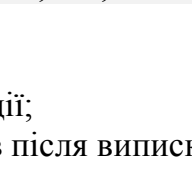 & anнi. & \\
\hline
\end{tabular}


* - при порівянні між показниками I групи, *1 - p>0,05, *2 - p<0,05;

\# - при порівянні між показниками II групи, $\#^{1}-\mathrm{p}>0,05, \#^{2}-\mathrm{p}<0,05$;

$€$ - при порівянні між показниками III групи, $€^{1}-\mathrm{p}>0,05, €^{2}-\mathrm{p}>0,05$;

$\S$ - при порівянні між показниками IV групи, $\S^{1}-\mathrm{p}>0,05, \S^{2}-\mathrm{p}>0,05$;

$¥-$ при порівянні між показниками V групи, $¥^{1}-\mathrm{p}>0,05, ¥^{2}-\mathrm{p}<0,05$.

При аналізі даних ліпідного обміну, статистично достовірних показників при порівнянні показників між I, II, III, IV та V групами до госпіталізації, на момент госпіталізації, а також між показниками груп на момент госпіталізації та через 6 місяців після госпіталізації, не спостерігалось ( $>>0,05)$ (табл. 2).

Таблиця 2. Динаміка рівня показників ліпідного профілю у пацієнтів 3 цукровим діабетом до, на момент госпіталізації та через 6 місяців після лікування $(\mathrm{M} \pm \mathrm{m})$

\begin{tabular}{|c|c|c|c|c|c|}
\hline \multirow{2}{*}{ Показник } & \multicolumn{5}{|c|}{ Група паціснтів в залежності від лікування } \\
\hline & I (n=22) & II $(n=18)$ & III (n=21) & IV $(n=13)$ & $V(n=13)$ \\
\hline 3Х до госпіталізації (ммоль/л) & $5,41 \pm 0,3$ & $5,0 \pm 0,4$ & $5,6 \pm 0,5$ & $5,4 \pm 0,3$ & $7,4 \pm 0,8$ \\
\hline $\begin{array}{l}\text { 3Х під час госпіталізації після } \\
\text { призначеного лікування (ммоль/л) }\end{array}$ & $6,41 \pm 0,4 * 1$ & $5,3 \pm 0,8 \#^{1}$ & $5,57 \pm 0,4 €^{1}$ & $5,29 \pm 0,2 \S^{1}$ & $7,11 \pm 0,4 ¥^{1}$ \\
\hline $\begin{array}{l}\text { 3Х через } 6 \text { місяців після виписки } \\
3 \text { лікарні (ммоль/л) }\end{array}$ & $6,3 \pm 0,4 * 2$ & $5,2 \pm 0,4 \#^{2}$ & $5,69 \pm 0,6 €^{2}$ & $5,2 \pm 0,4 \S^{2}$ & $6,8 \pm 0,3 ¥^{2}$ \\
\hline ק-ліпопротеїди до госпіталізації (од.) & $85,0 \pm 2,5$ & $70,0 \pm 3,2$ & $72,3 \pm 4,8$ & $105,2 \pm 1,3$ & $95,0 \pm 4,8$ \\
\hline $\begin{array}{l}\text { B-ліпопротеїди під час госпіталізації } \\
\text { після призначеного лікування (од.) }\end{array}$ & $80,9 \pm 6,8^{* 1}$ & $70,6 \pm 10,9 \#^{1}$ & $63,8 \pm 5,8 €^{1}$ & $107,0 \pm 13,0 \S^{1}$ & $92,0 \pm 6,1 ¥^{1}$ \\
\hline $\begin{array}{l}\text { } \beta \text {-ліпопротеїди через } 6 \text { місяців після } \\
\text { виписки з лікарні (од.) }\end{array}$ & $75 \pm 3,6 * 1$ & $73,2 \pm 6,9 \#^{2}$ & $65,4 \pm 4,6 €^{2}$ & $102,5 \pm 2,5 \S^{2}$ & $90,2 \pm 5,5 ¥^{2}$ \\
\hline
\end{tabular}

Примітки:

3Х - загальний холестерин;

1 - при порівянні між показниками до госпіталізації та під час госпіталізації;

2 - при порівянні між показниками під час госпіталізації та через 6 місяців після виписки з лікарні;

* - при порівянні між показниками І групи, *1 - p>0,05, *2 - p>0,05;

\# - при порівянні між показниками II групи, $\#^{1}-\mathrm{p}>0,05, \#^{2}-\mathrm{p}>0,05$;

$€$ - при порівянні між показниками III групи, $€^{1}-\mathrm{p}>0,05, €^{2}-\mathrm{p}>0,05$;

$\S$ - при порівянні між показниками IV групи, $\S^{1}-\mathrm{p}>0,05, \S^{2}-\mathrm{p}>0,05$;

$¥-$ при порівянні між показниками V групи, $¥^{1}-p>0,05, ¥^{2}-p>0,05$.

\section{Перспективи подальших досліджень}

Плануємо провести дослідження 3 порівнянням ефективності різних комбінацій лікування у пацієнтів з ЦД 2 типу при різних видах дієти та фізичного навантаження.

\section{Висновки}

Використання пероральних препаратів, зокрема метформіну та комбінацій 3 ним, в тому числі 3 емпагліфлозином, супроводжувалось більш вираженим та поступовим зменшенням показників глюкози та HbA1c в пацієнтів з ЦД 2-го типу, в порівнянні з використанням ін'єкційних інсулінів.

За період лікування пацієнтів різними групами антидіабетичних препаратів не було виявлено статистично достовірного впливу на показники ліпідного профілю $(\mathrm{p}>0,05)$.

\section{Література}

1. Всесвітній день боротьби 3 діабетом: що треба знати про хворобу. Міністерство охорони здоров'я від 14 листопада 2017 року. Режим доступу - https://moz.gov.ua/article/health/vsesvitnij-den-borotbi-z-diabetom-scho-trebaznati-pro-hvorobu.

2. Наказ Міністерства охорони здоров’я від 21 грудня 2012 року № 1118, Уніфікований клінічний протокол первинної та вторинної (спеціалізованої) медичної допомоги Цд 2-го типу. Режим доступу - https://dec.gov.ua/wpcontent/uploads/images/dodatki/2012_1118/2012_1118YKPMD.pdf.

3. Цитовський М. Н. Статистичний, клінічний та морфологічний аспекти впливу цукрового діабету на стан ССС / М. Н. Цитовськкий // Науковий вісник Ужгородського університету, серія «Медицина». - 2017. Випуск 1 (55). - С. 168-177. 
4. American Diabetes Association, et al. 9. Pharmacologic approaches to glycemic treatment: Standards of Medical Care in Diabetes // Diabetes care. - 2019. - 42.Supplement 1: S90-S102.

5. Cefalu W.T. American Diabetes Association Standards of Medical Care in Diabetes / G. Bakris, L. Blonde, J.M. Boulton // Diabetes Care - 2017 - № 40 - P. 6-10.

6. George A.B. Handbook of obesity: epidemiology, etiology, and physiopathology / A. B. George, C. Bouchard // CRC Press Taylor \& Francis Group - 2014 - № 1 - P. 539-549.

7. Fiaccadori E. Targeting the Gut for Early Diagnosis, Prevention, and Cure of Diabetic Kidney Disease: Is the Phenyl Sulfate Story Another Step Forward? / E. Fiaccadori, C. Cosola, A. Sabatino // American Journal of Kidney Diseases - 2020. Vol. 75.1. - P. 144-147.

8. Saydah S.H. Poor control of risk factors for vascular disease among adults with previously diagnosed diabetes / S.H. Saydah, J. Fradkin, C.C. Cowie // JAMA - 2014 - № 42 - P. 291-335.

9. Tan Y. Mechanisms of diabetic cardiomyopathy and potential therapeutic strategies: preclinical and clinical evidence / Y. Tan, Z. Zhang, C. Zheng et all // Nature Reviews Cardiology. - 2020. - P. 1-23.

\title{
References
}

1. Vsesvitnij den` borot’by` $\mathrm{z}$ diabetom: shho treba znaty` pro xvorobu. Ministerstvo oxorony`zdorov’ya vid 14 ly`stopada 2017 roku. Rezhy`m dostupu - https://moz.gov.ua/article/health/vsesvitnij-den-borotbi-z-diabetom-scho-trebaznati-pro-hvorobu.

2. Nakaz Ministerstva oxorony`zdorov’ya vid 21 grudnya 2012 roku \# 1118, Unifikovany`j klinichny`j protokol pervy`nnoyi ta vtory`nnoyi (specializovanoyi) medy`chnoyi dopomogy`CzD 2-go ty`pu. Rezhy`m dostupu - https://dec.gov.ua/ wp-content/uploads/images/dodatki/2012_1118/2012_1118YKPMD.pdf.

3. Cy`tovs`ky`j M. N. Staty`sty`chny`j, klinichny`j ta morfologichny`j aspekty`vply`vu czukrovogo diabetu na stan SSS / M. N. Cy`tovs`kky`j // Naukovy`j visny`k Uzhgorods`kogo universy`tetu, seriya «Medy`cy`na». - 2017. Vy`pusk 1 (55). - S. 168-177.

4. American Diabetes Association, et al. 9. Pharmacologic approaches to glycemic treatment: Standards of Medical Care in Diabetes // Diabetes care. - 2019. - 42.Supplement 1: S90-S102.

5. Cefalu W.T. American Diabetes Association Standards of Medical Care in Diabetes / G. Bakris, L. Blonde, J.M. Boulton // Diabetes Care. - 2017 - № 40 - P. 6-10.

6. George A.B. Handbook of obesity: epidemiology, etiology, and physiopathology / A. B. George, C. Bouchard // CRC Press Taylor \& Francis Group - 2014 - № 1 - P. 539 - 549.

7. Fiaccadori E. Targeting the Gut for Early Diagnosis, Prevention, and Cure of Diabetic Kidney Disease: Is the Phenyl Sulfate Story Another Step Forward? / E. Fiaccadori, C. Cosola, A. Sabatino // American Journal of Kidney Diseases - 2020. Vol. 75.1. - P. 144-147.

8. Saydah S.H. Poor control of risk factors for vascular disease among adults with previously diagnosed diabetes / S.H. Saydah, J. Fradkin, C.C. Cowie // JAMA - 2014 - № 42 - P. 291-335.

9. Tan Y. Mechanisms of diabetic cardiomyopathy and potential therapeutic strategies: preclinical and clinical evidence / Y. Tan, Z. Zhang, C. Zheng et all // Nature Reviews Cardiology. - 2020. - P. 1-23.

Дата надходження рукопису до редакції: 23.06.2020 p.

\begin{abstract}
Мета. Порівняти вплив різних схем лікування у хворих на цукровий діабет (ЦД) 2-го типу на показники вуглеводного та ліпідного обміну обмінів.

Матеріали та методи. На базі терапевтичного відділення комунального некомерційного підприємства «Ужгородська районна клінічна лікарня Ужгородської районної ради Закарпатської області» було обстежено 87 пацієнтів з діагнозом ЦД 2-го типу в період з квітня 2019 по лютий 2020 року. Всі в подальшому отримані дані, були статистично оброблені.

Результати. В процесі лікування та через 6 місяців після виписки у пацієнтів всіх груп відмічалось покращення вуглеводного обмінів, проте статистично значимі результати були виявлені в пацієнтів які отримували терапію метформіном, метформін у комбінації з глімепіридом, а також метформін у комбінації з емпагліфлозином- (р<0,05). Разом $з$ тим, статистично достовірних змін показників ліпідного обміну до та після отриманого лікування в пацієнтів всіх дослідних груп не відмічалось $(p<0,05)$. I тільки в пацієнтів, які отримували терапію метформіном, а також метформін у комбінації з емпагліфлозином через 6 міс після виписки був досягнутий цільовий рівень НbА1с.

Висновки. Використання пероральних препаратів, зокрема метформіну та комбінацій 3 ним, в тому числі 3 емпагліфлозином, супроводжувалось більш вираженим та поступовим зменшенням показників глюкози та НbА1с в пацієнтів з ЦД 2-го типу, в порівнянні з використанням ін'єкційного інсуліну.
\end{abstract}

Ключові слова: цукровий діабет 2-го типу, цукрознижуючі препарати, вуглеводний обмін, ліпідний обмін. 
Цель. Сравнить влияние различных схем лечения у больных сахарным диабетом (СД) 2-го типа на показатели углеводного и липидного обмена обменов.

Материалы и методы. На базе терапевтического отделения коммунального некоммерческого предприятия «Ужгородская районная клиническая больница Ужгородского районного совета Закарпатской области» было обследовано 87 пациентов с диагнозом СД 2-го типа в период с апреля 2019 по февраль 2020 года. Все в дальнейшем полученные данные были статистически обработаны.

Результаты. В процессе лечения и через 6 месяцев после выписки у пациентов всех групп отмечалось улучшение углеводного обмена, однако статистически значимые результаты были обнаружены у пациентов получавших терапию метформином, метформин в комбинации с глимепиридом, а также метформин в комбинации с емпаглифлозином $(\mathrm{p}<0,05)$. Зато статистически достоверных изменений показателей липидного обмена до и после полученного лечения у пациентов всех исследовательских групп не отмечалось $(\mathrm{p}<0,05)$. И только у пациентов, получавших терапию метформином, а также метформин в комбинации с емпаглифлозином через 6 мес после выписки был достигнут целевой уровень $\mathrm{HbA1c.}$

Выводы. Использование пероральных препаратов, в частности метформина и комбинаций с ним, в том числе с емпаглифлозином, сопровождалось более выраженным и постепенным уменьшением показателей глюкозы и НbА1с у пациентов с СД 2-го типа, по сравнению с использованием инъекционного инсулина.

Ключевые слова: сахарный диабет 2-го типа, сахароснижающие препараты, углеводный обмен, липидный обмен.

Purpose. To compare the effect of different treatment regimens in patients with type 2 diabetes mellitus (DM) on carbohydrate and lipid metabolism.

Materials and methods. On the basis of the therapeutic department of the municipal non-profit enterprise "Uzhhorod district clinical hospital of Uzhhorod district council of Zakarpattia region" 87 patients with a diagnosis of type 2 diabetes were examined in the period from April 2019 to February 2020. All subsequent data were statistically processed.

Results. During treatment and 6 months after discharge, patients in all groups showed an improvement in carbohydrate metabolism, but statistically significant results were found in patients treated with metformin, metformin in combination with glimepiride and metformin in combination with empagliflozin - $(\mathrm{p}<0,05)$. In contrast, statistically significant changes in lipid metabolism before and after treatment in patients of all experimental groups were not observed $(\mathrm{p}<0.05)$. And only in patients receiving metformin therapy, as well as metformin in combination with empagliflozin 6 months after discharge was reached the target level of HbAlc.

Conclusions. The use of oral drugs, including metformin and combinations with it, including empagliflozin, was associated with a more pronounced and gradual decrease in glucose and HbA1c in patients with type 2 diabetes compared with injectable insulin.

Key words: type 2 diabetes, hypoglycemic drugs, carbohydrate metabolism, lipid metabolism.

Конфлікт інтересів: відсутній.

Conflicts of interest: authors have no conflicts of interest to declare.

\section{Відомості про авторів}

Гряділь Тарас Іванович - аспірант, магістр медицини, клінічний ординатор за спеціальністю «Загальна практикасімейна медицина», факультету післядипломної освіти та доуніверситетської підготовки, ДВНЗ «Ужгородський національний університет»; пл. Народна, 3, м. Ужгород, Закарпатська обл., 88000, Україна.

Дурунда Маріанна Іванівна - лікар-терапевт, асистент кафедри внутрішніх хвороб медичного факультету № 2, ДВНЗ «Ужгородський національний університет»; пл. Народна, 3, м. Ужгород, Закарпатська обл., 88000, Україна.

mar-durunda@ukr.net.

Чопей Іван Васильович - д.мед.н., проф. кафедри терапії та сімейної медицини, декан факультету післядипломної освіти та доуніверситетської підготовки ДВНЗ «Ужгородський національний університет»; пл. Народна, 3, м. Ужгород, Закарпатська обл., 88000, Україна.

ivchopey@hotmail.com.

Товт-Коршинська Маріанна Іванівна - д.мед.н., проф., завідувач кафедри внутрішніх хвороб медичного факультету № 2, ДВНЗ «Ужгородський національний університет»; пл. Народна, 3, м. Ужгород, Закарпатська обл., 88000, Україна. 